\title{
A Fair and Impartial Jury? \\ The Role of Age in Jury Selection and Trial Outcomes
}

Shamena Anwar

Carnegie Mellon

University
Patrick Bayer

Duke University

February 2012
Randi Hjalmarsson

Queen Mary University of London

ERID Working Paper Number 125

This paper can be downloaded without charge from

the Social Science Research Network Electronic Paper Collection:

http://ssrn.com/abstract=2014963

\section{Economic Research Initiatives at Duke WORKING PAPERS SERIES}

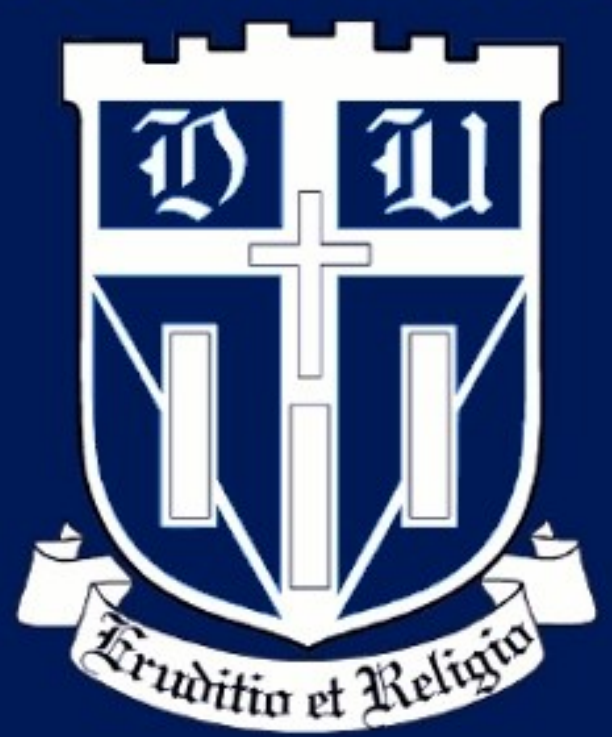




\title{
A FAIR AND IMPARTIAL JURY? THE ROLE OF AGE IN JURY SELECTION AND TRIAL OUTCOMES
}

\author{
SHAMENA ANWAR \\ PATRICK BAYER \\ RANDI HJALMARSSON
}

February 2012

\begin{abstract}
This paper uses data from over 700 felony trials in Sarasota and Lake Counties in Florida from 2000-2010 to examine the role of age in jury selection and trial outcomes. The results of the analysis imply that prosecutors are more likely to use their peremptory challenges to exclude younger members of the jury pool, while defense attorneys exclude older potential jurors. Having established that age has an important role in jury selection, the paper employs a research design that isolates the effect of the random variation in the age composition of the pool of eligible jurors called for jury duty to examine the causal impact of age on trial outcomes. Consistent with the jury selection patterns, the empirical evidence implies that older jurors are indeed more likely to convict. These results are robust to the inclusion of a broad set of controls for the racial and gender composition of the jury and a series of county, time, and judge fixed effects; almost identical effects are estimated separately for each county. These findings have implications for the role that the institution of peremptory challenges has on a defendant's right to a fair trial and to an eligible citizen's rights to serve on a jury.
\end{abstract}




\section{Introduction}

The Sixth Amendment right to a fair and impartial jury of one's peers is the bedrock of the American criminal justice system. Yet citizens are not randomly chosen to sit on juries. Instead, attorneys have the power to shape the composition of the seated jury through the use of peremptory challenges. Historically, such challenges could be used to exclude potential members of the jury "without cause, without explanation and without judicial approval" and, not surprisingly, this has raised concerns about the systematic exclusion of jurors on the basis of observable attributes (e.g., race, gender, age) and the ultimate impartiality of seated juries. ${ }^{1}$

In recent years, in Batson v. Kentucky (1986) and J.E.B. v. Alabama (1994), the US Supreme Court has ruled that challenges motivated solely by race or gender violate the equal protection clause of the US Constitution. The Court has not extended this protection to any other category of juror characteristics and thus, under current case law, it is perfectly legal for attorneys to exclude potential jurors on the basis of age, religion, or any other unprotected category. ${ }^{2}$ A spirited debate continues in the courts and academy about whether discrimination on these bases should be allowed and even whether peremptory challenges should be abolished altogether. ${ }^{3}$

With this broad debate in mind, the goal of this paper is to examine the role of an important unprotected category, age, in jury selection and trial outcomes. To date, very little is known about whether attorneys systematically exclude potential jurors on the basis of age or whether juror age is even a clear predictor of conviction rates. ${ }^{4}$ The lack of compelling evidence to date is likely due, in large part, to the fact that few courts systematically collect age-specific data for summoned and/or seated jurors (Entzel, Dunlop, and Rothman 2000). A sparse literature has examined the relationship between juror age

\footnotetext{
${ }^{1}$ See Beck (1998) or Page (2005) for more detailed discussion of the historical evolution of the use of peremptory challenges in the United States.

${ }^{2}$ One exception is the Connecticut Supreme Court's extension to outlaw peremptory challenges on the basis of religion (State v. Hodge 1999).

${ }^{3}$ Weber v. Strippit, Inc (1999) declined to extend Batson to peremptory challenges based on age. See also Marder (1995), Reid (2004), Montz and Montz (2000), Fahey (1997), Chase and Graffy (1997), Montoya (1996), Broderick (1992), Hoffman (1997), and Page (2005).

${ }^{4}$ Age discrimination has been studied extensively in the labor market and other contexts - see, for example, Johnson and Neumark (1997), Macinol (2005) and Neumark and Stock (1999).
} 
and trial outcomes using post-trial surveys of jurors; these studies have generally found no evidence or inconsistent evidence of an effect of juror age on verdict, but potential biases due to the non-random selection of the jury have not been addressed in this literature. ${ }^{5,6}$ There is also limited evidence, though much of it is anecdotal, that attorneys exercise their peremptory challenges to exclude jurors on the basis of age. ${ }^{7,8}$

To examine the role of age in jury selection and decisions, we have assembled a data set for over 700 felony trials in Lake and Sarasota Counties, Florida between 2000-2010. In both counties, we observe the race, gender, and age not only of each member of the seated jury but also the jury pool. This allows us to examine how juror attributes affect the propensity of members of the jury pool to be seated. ${ }^{9}$ Moreover, for Lake County, we observe the reason that an excluded member of the jury pool did not make it onto the seated jury - i.e., whether he/she was excluded for cause, or excluded by a peremptory challenge by the prosecutor or defense attorney, respectively. Finally, for each trial we observe detailed information about the defendant and criminal charges as well as the jury's verdict on each charge.

Our analysis proceeds in two main parts. We begin by examining the role of juror age in the selection process. Using the Lake County data, we show that prosecutors are systematically more likely to exclude younger members of the jury pool, while defense attorneys do the exact opposite - they disproportionately exclude older members of the jury pool. As a result, both the youngest and oldest members of the jury pool are less likely to be seated than those in the middle of the age distribution.

\footnotetext{
${ }^{5}$ There is a much more extensive literature that looks at other demographic characteristics, such as race and gender, using both post-trial surveys and mock juries; mock juries have not been extensively used to study age. Reviews of this research indicate that there is little evidence of a consistent and significant relationship between demographic characteristics and verdicts in criminal trials (Devine et al 2000, Bonazzoli 1998-1999, and Overland 2008).

${ }^{6}$ See Garvey et al (2004), Mills and Bohannon (1980), Baldwin and McConville (1980), Moran and Comfort (1982), and Eisenberg et al (2001) for examples of studies of the relationship between juror age and verdict that rely on juror recall.

${ }^{7}$ Many attorneys openly acknowledge using age as one basis for peremptory challenges. It is also routine for agebased explanations to be offered to the courts when peremptory strikes are alleged to be improperly based on race and/or gender. See Entzel, Dunlop and Rothman (2000) for relevant cases.

${ }^{8}$ Baldus et. al (2001) study the use of peremptory strikes in Philadelphia capital cases. With regards to age, they found that prosecutors were more likely to strike younger jurors while the opposite was found for the defense.

${ }^{9}$ In Anwar, Bayer, Hjalmarsson (forthcoming), we use this data to study the impact of jury race on verdict. We find evidence that: (i) juries formed from all-white jury pools convict black defendants significantly (16 percentage points) more often than white defendants and (ii) this gap in conviction rates is entirely eliminated when the jury pool includes at least one black member.
} 
Interestingly, this pattern of selection contrasts with that for the protected categories of race and gender. For these categories, we find that both sides (prosecutors and defense attorneys) are about equally likely to exclude white versus black and male versus female members of the jury pool.

Having established the systematic use of age in jury selection, the second part of our analysis considers the role of juror age on trial outcomes. Establishing the causal impact of any juror characteristic on trial outcomes is generally not straightforward, precisely because of the peremptory challenge process. In particular, the seated jury on any trial is made up of those members of the jury pool that made it through the jury selection process and, as a result, the composition of the seated jury is certainly not random. Given concerns about the non-random selection of the seated jury, our research design instead exploits the variation in the composition of the jury pool across trials, which is driven primarily by which eligible jurors in the county are randomly called for jury duty on a given day. ${ }^{10}$ In essence, we examine how conviction rates vary with the age composition of the jury pool rather than the seated jury. This dayto-day variation in the composition of the jury pool does in fact appear to be random - the composition of the pool is uncorrelated with the characteristics of the defendant and the criminal charges. ${ }^{11}$

The evidence regarding the impact of the jury pool on conviction rates is straightforward and striking: when the average age of the jury pool is greater than 50 (which happens in about half of the trials), defendants are convicted 79 percent of the time. In contrast, when the average age of the jury pool is less than 50, conviction rates are only 68 percent. These differences are statistically significant. More generally, we find that conviction rates increase by about 1 percentage point for each year increase in the average age of the jury pool. The effects of jury age on conviction rates do not vary with the race of the defendants. They do, however, vary with the gender of the defendant: there is a positive relationship

\footnotetext{
${ }^{10} \mathrm{~A}$ handful of studies utilize random variation in other aspects of the criminal justice system. Abrams, Bertrand, and Mullainathan (forthcoming) use the random assignment of judges to study racial disparities in sentencing. Kling (2006) uses random judge assignment as a source of exogenous variation in sentence length. Abrams and Yoon (2007) use the random assignment of felony cases to public defenders to study the effect of attorney ability on case outcomes.

${ }^{11}$ The age composition of the jury pool is also highly correlated with the composition of the seated jury: a higher fraction of older (younger) jurors are seated when there is a higher fraction of older (younger) jurors in the pool drawn for that trial.
} 
between juror age and conviction rates among male defendants, but a negative relationship among female defendants. Because the majority of the defendants in the sample are male, the overall results match closely to those for male defendants. The estimated results are very robust to the inclusion of a broad set of controls for the racial and gender composition of the jury and a series of county, time, and judge fixed effects. A qualitatively similar pattern of results is found in both Lake and Sarasota Counties.

We conclude the paper with a discussion of the implications of our findings for the debate over extending the protection currently provided for gender and race to age - i.e., abolishing age-based peremptory challenges. Given that attorneys are systematically more likely to exclude the youngest and oldest members of the jury pool (relative to middle-aged jurors), such a policy would clearly provide more equal protection of the rights of these citizens to serve on juries. However, removing age-based peremptory challenges would also increase the variance of the average age of the seated jury - by about 13 percent in our sample. And, because juror age has a causal effect on trial outcomes, this would, in turn, increase the variation in the outcomes in trials with comparable cases. Thus, in the case of age, there appears to be a clear trade-off between protecting the right of citizens to serve on juries and the equal application of criminal justice. This trade-off could be mitigated, however, by increasing the size of juries. We estimate, for example, that increasing the jury size in Florida from six to eight would reduce the variance of the age of seated juries enough to offset the increased variance due to the random seating of jurors.

The remainder of the paper proceeds as follows. Section II provides background information on jury selection in Sarasota and Lake County while Section III describes the data. Section IV presents our analysis of the jury selection process and Section $\mathrm{V}$ presents our findings on the impact of jury age composition on conviction rates, including a number of alternative specifications that establish the robustness of our main findings. Section VI concludes by discussing the implications of our findings for the fair and equal application of the law. 


\section{The Jury Selection Process}

Our analysis is based on a sample of non-capital felony jury trials in Sarasota County and Lake County. Each county has a master jury list, which is a list of potential jurors that is compiled from driver's license records. Both counties use a jury management software program to randomly choose individuals from this master list to receive a summons requesting that they appear at the courthouse on a particular date. Potential jurors are only eligible to serve if they are a U.S. citizen, are a legal resident of either Sarasota or Lake County, able to speak/understand English, and not under a legal disability (felony conviction or incompetence). In addition, some individuals who receive a summons are eligible for an automatic exemption and need not appear in court. ${ }^{12}$

Individuals who are not exempt and who are eligible to serve check-in on the date summoned; upon check-in, they are entered into the jury management software program. From the sample of checked-in individuals, this software randomly chooses individuals to participate in a particular panel. It is important to note that the jury management software program only utilizes data about jurors and does not have information about the defendants or case characteristics. Individuals whose names are called out enter the courtroom to participate in voir dire.

During the voir dire process, both the attorneys (defense and prosecution) and the judge ask the potential jurors a series of questions, which are designed to determine whether the individual is fit to serve as an impartial member of the jury. Some individuals are simply excused from service, perhaps because of a medical condition. Other individuals are removed for cause by the judge because they cannot be impartial or follow the law. Both prosecutor and defense attorneys can request a removal for cause, and there is generally no limit to the amount of such requests. Finally, both the prosecutor and defense attorneys have the option to use peremptory challenges to strike potential jurors from the jury. Such challenges are differentiated from removals for cause in that attorneys do not have to state the

\footnotetext{
${ }^{12}$ Individuals can be automatically excused if: (i) they are an expectant mother, (ii) they are a parent who is not employed full time and has custody of a child under 6, (iii) they are a full time law enforcement officer, (iv) they served as a juror in Sarasota county in the last 365 days, (v) they are responsible for the care of another who is incapable of caring for himself, or (vi) they are 70 or older and wish not to report (at this time or permanently).
} 
reason for the strike and there are a limited number of peremptory challenges available to both the prosecution and defense. Though the attorneys do not have to provide a reason for dismissing a juror, a peremptory challenge cannot be used to strike a juror solely on the basis of race or gender, although striking based on age is permitted. If the offense is punishable by imprisonment of more than 12 months, then attorneys for both the defense and prosecution have six challenges; for all other offenses, there are three challenges. The first six jurors to survive the voir dire make up the seated jury. In addition, $0-2$ alternate jurors are also chosen at this time through the same process. ${ }^{13}$

After hearing the evidence, the six seated jurors need to come to a unanimous decision of guilty or not guilty for each of the defendant's charges. If jurors cannot come to a unanimous decision for a particular charge, there will be a hung jury for that charge. This typically results in the defendant being retried on that particular charge. ${ }^{14}$

\section{Data}

\section{III.A. Description of Jury Data from Sarasota and Lake Counties}

Our analysis is conducted using felony jury trial data for Lake County and Sarasota County, Florida. As each county circuit court maintains their own records of jury trials, these data were obtained through separate requests to each county. ${ }^{15}$ Since a standardized record system is not used throughout Florida, the type of information and format of the data available vary somewhat across counties. Thus, the majority of our analysis is conducted with a single, combined data set of Lake and Sarasota County trials,

\footnotetext{
${ }^{13}$ The jury selection process described above pertains only to non-capital cases in Lake and Sarasota County. While many of the core details remain the same, the process can vary slightly when considering different jurisdictions or capital cases. The main differences are where the master jury list is composed from, the number of peremptory challenges the prosecution and defense have, and the size of the seated jury.

${ }^{14}$ Since a hung jury is an interim disposition from the court's perspective, most courts do not systematically collect and publish statistics regarding hung jury rates (Hannaford-Agor et. al 2002). Hannaford-Agor et. al (2002) began to address this issue in a study of hung jury rates for 30 state courts and federal courts between 1980 and 1997. They found that about five percent of state felony jury trials resulted in a hung jury, though there was substantial variation across jurisdictions. Federal hung jury rates for criminal trials were even lower, between two and three percent, and those for civil trials were lower still.

${ }^{15}$ To obtain the data used in this paper, we sent data request letters to every felony court in fifteen states. Most courts indicated that they were unable to provide data because either judicial records are excluded from public records request or these data are not collected or maintained.
} 
using those variables that can be commonly identified in both counties. Following is a brief description of the data obtained for each county as well as the combined data set.

The office of the Clerk of the Sarasota County Circuit Court provided us with information on all felony trials for which jury selection began between January 1, 2004 and June 1, 2009. ${ }^{16}$ For each trial, we have data for both the defendant and the jury. The defendant data includes the name, race, and gender of the defendant as well as information about the charged offenses, including a detailed crime code, the date that the offense was filed, the date that the judgment was handed down, and the verdict for each offense. For our main analysis, we restrict our sample to trials in which at least one of the charged offenses resulted in a verdict of guilty or not guilty by the jury. ${ }^{17}$ The jury data includes the name, date of birth, gender, and race of each individual in the jury pool as well as whether or not they were seated. However, we cannot distinguish between individuals who are seated and those who became alternates; all of these individuals appear to be 'seated'.

Data were also provided to us by the Lake County Clerk of Courts for all felony jury trials from March 1, 2000 to April 2, 2010. As in Sarasota County, we know each potential juror's name, race, gender, date of birth, and whether they were seated or assigned as alternates. In addition to this, we also know whether jurors were struck for cause or whether the prosecution or defense struck them with their peremptory challenges. This information is not available in Sarasota County. In terms of the defendant information, the Lake County Clerk of Courts only provided the case number and defendant name. We used this information to manually collect the following information from the Lake County Clerk of Courts Online Court Records website: city of residence, sex, race, attorney, judge, the number of charges,

\footnotetext{
${ }^{16}$ Note that because of the (oftentimes long) lag between the date at which an offense is filed with the courts and the date at which a verdict is rendered, our data set contains trials for offenses dating as far back as 1999.

${ }^{17}$ Charges for which the verdict was neither guilty nor not guilty had the following possible outcomes: dropped, noelle prosequi, filed, dismissed due to speedy trial, dismissed with no reason given, consolidated, adjudication withheld by judge and unable to stand trial. We test the sensitivity of our results to the exclusion of these cases in Table 7.
} 
the type of charge, and the verdict for each charge. ${ }^{18}$ As in Sarasota, we restrict our sample to trials in which at least one of the charged offenses resulted in a verdict of guilty or not guilty by the jury. ${ }^{19}$

Since all felony trials in Florida other than capital trials have six-member juries, we exclude capital trials from our analysis. Since each jury should have six members plus zero to two alternates, we drop those cases with less than six jurors/alternates identified in the data and those with more than 8 . We also drop those cases with multiple defendants and those in which the defendant names do not match the online record (i.e. in Lake County). We are left with a dataset of 785 felony jury trials, 401 of which are from Sarasota County and 384 of which are from Lake County.

\section{III.B. Summary Statistics}

Table I presents descriptive statistics for both the defendant and jury variables for all 785 felony trials overall and separately for Lake and Sarasota counties. Overall, 44 percent of defendants are black, and 92 percent are male. The average number of charges per defendant is 2.99 . We identify whether each defendant is charged with an offense in the following categories, regardless of the verdict associated with the charge: murder (non-capital), robbery, other violent offenses, property offenses, drug offenses, sex offenses, weapons offenses, and other offenses. Overall, the most common crime categories are other offenses (33 percent), other violent offenses (31 percent), and drug offenses ( 25 percent).

We consider two possible outcome measures or verdicts: whether the defendant was convicted of at least one offense and the percent of the first five offenses for which the defendant was convicted. 72.8 percent of defendants were convicted of at least one offense. On average, seated juries have seven members (including alternates) drawn from jury pools with 27 individuals. In Lake County, where we have detailed strike information, we find that on average 2.2 jurors in the pool are struck for cause, 4.5

\footnotetext{
${ }^{18}$ The data were collected from the following website: http://www.lakecountyclerk.org/record searches/court_records agreement.aspx?to $=\% 2$ Frecord $\% 5$ Fsearches $\% 2$ Fonl ine $\% 5$ Fcourt $\% 5$ Frecords $\% 2$ Fonline $\% 5$ Fcourt $\% 5$ Frecords $\% 2$ Easp? target $\% 3 \mathrm{D} \% 5$ Fblank.

${ }^{19}$ Other possible verdicts include: pled, nolle prosequi, no information, dismissed by judge, and mistrial. We will test the sensitivity of our results to redefining pleas as decisions of guilty by the jury.
} 
jurors are struck by a defense peremptory challenge, and 3.4 jurors are struck by a prosecution peremptory challenge.

The average age of jurors in the pool is 49.6 years, and 46 percent of jury pools have an average age that is greater than or equal to 50 years. The age composition in Sarasota County is slightly older (49.9) than in Lake County (49.4). The average age of the seated jury tends to be slightly older than the average age of the pool, implying older jurors are more likely to be seated. While this difference is observed in both counties, it is more pronounced in Sarasota County. ${ }^{20}$

\section{The Role of Juror Demographics in the Selection Process}

As mentioned previously, it is perfectly legal for attorneys to use their peremptory challenges to exclude potential jurors on the basis of age. If attorneys use these challenges as a strategic way to eliminate jurors that are unfriendly to their case due to their age, we would expect the defense strike pattern to be the opposite of the prosecution strike pattern. Column 1 of Table 2 examines whether this is the case for Lake County, where we observe information about the use of peremptory challenges by each side. The regression includes the entire pool of Lake County jurors. We regress the juror's age on indicator variables for whether she/he was struck for cause, struck by a defense peremptory challenge, struck by a prosecution peremptory challenge, or remained in the jury pool after the selection process was over. ${ }^{21}$ The excluded category is an indicator for whether the individual was on the seated jury for the trial. The results show that the average seated juror is 49.4 years old, while the average juror struck by the defense is 51.6 years old, and the average juror struck by the prosecution is 47.1 years old. This implies that defense attorneys strike relatively older members of the jury pool while prosecutors strike relatively younger ones.

\footnotetext{
${ }^{20}$ While not reported in Table I, the average composition of the jury pools is 4 percent black and 51 percent female.

${ }^{21}$ Some of these jurors remaining in the pool were suitable to be seated but were not needed. Others were so far back in the pool they did not even go through the questioning process that could potentially have led to them being struck.
} 
In Columns 2 and 3 the dependent variable is defined as an indicator for whether the juror is male, and an indicator for whether the juror is black, respectively, to examine the strike pattern for the protected categories of gender and race. The results in Column 2 imply that attorneys do not use gender as a factor when they use their peremptory challenges, because both the prosecution and defense are just as likely to strike male jurors as they are female jurors. The results for race in Column 3 show that both the defense and prosecution are less likely to strike black jurors than white jurors. ${ }^{22}$ Technically, this means attorneys are taking race into account when they make their strike decisions. However, they do not seem to be doing this in a strategic way (i.e. using race as a factor to strike jurors unfriendly to their case), because otherwise we would expect one side to be more likely to strike black jurors, and the other group to be less likely. The fact that both attorneys are less likely to strike black jurors might instead indicate attorneys go overboard in not striking blacks so they cannot be accused of violating the ruling in Batson v. Kentucky. This is especially likely to be a concern in Lake County where only 5 percent of the jury pool is black, making it easy to notice the systematic use of peremptory challenges to exclude black jurors.

\section{The Effect of Juror Age on Conviction Rates}

The fact that defense and prosecution attorneys have opposite strike patterns when it comes to juror age suggests that attorneys believe juror age is likely to have an effect on trial outcomes. We now take up this question directly, examining the causal impact of juror age on trial outcomes. Because the seated jury is determined in part by non-random peremptory challenges, the composition of the seated jury may be correlated with the nature of the charges and evidence in the case, as well as the attributes of the defendant. We thus instead focus on how conviction rates vary with the age composition of the jury pool, as this variation is driven by the automated random selection of the eligible jurors who are called for jury duty on any given day.

\footnotetext{
${ }^{22}$ This same result occurs for the subsamples of cases involving only black defendants or only white defendants.
} 
As a basic test of whether the age composition of the jury pool is effectively random, Table 3 examines the correlation of the age composition of the jury pool with defendant and case characteristics. Specifically, we regress the average age of the pool, as well as an indicator for whether the average age of the pool is greater than or equal to 50 , on observable defendant and case characteristics. ${ }^{23}$ If the jury pool were truly randomly assigned to cases, the regression coefficients should be close to zero and statistically insignificant in the vast majority of cases. This is exactly what we find, as just two of the 24 coefficients presented in this table are statistically significant at the 10 percent level and the magnitudes of all coefficients are quite small. ${ }^{24}$ While these regressions cannot rule out the possibility that the composition of the jury pool is related to attributes of the defendant or case that are unobserved to us, they suggest that this should not be a major concern. These results are also consistent with the jury management software properly randomly choosing potential jurors from the master list to receive summons for jury duty and randomly choosing from amongst the summoned individuals those who will participate in voir dire for a particular trial. $^{25}$

Table 4 presents simple cross tabulations that show how conviction rates vary with the average age of the jury pool. There is a general upward trend such that defendants are more likely to be convicted of at least one charge as the average age of the pool increases. In particular, the table indicates that there is a sharp difference in conviction rates between jury pools that have an average age of 50 or older versus those with an average age less than 50 .

Table 5 examines the relationship between conviction rates and the age of the jury pool in regression format. Column 1 regresses an indicator of whether a defendant is convicted of at least one crime on the average age of the jury pool. The results indicate increasing the average age of the jury pool

\footnotetext{
${ }^{23}$ Note that 14 cases are dropped from these regressions due to incomplete charge information.

${ }^{24}$ Additional regressions of the gender and racial composition of the pool on the defendant and case characteristics (not shown) provide further evidence of random assignment, as just two of 48 coefficients are significant at the ten percent level.

${ }^{25}$ As would be expected, the age composition of the jury pool is highly positively correlated with the age composition of the seated jury. In regressing the average age of the seated jury on the average age of the pool (results not shown) we find that for every one year increase in the average age of the jury pool, the average age of the seated jury increases by 0.97 years. The F-statistic associated with this first stage regression is 339.7.
} 
by one year increases conviction rates by one percentage point. The specification in Column 2 includes controls for the racial and gender composition of the jury pool, defendant and case characteristics (race, gender, offense category and number of offenses), as well as county, year and judge controls. Including controls for other characteristics of the jury pool accounts for potential correlations between jury race, gender, and age. The coefficients on the age of the jury pool are similar across both specifications.

Columns 3 and 4 of Table 5 repeat the previous specifications using an indicator for whether the average age of the pool is greater than or equal to 50 as the key age variable. This age specification was used because while the cross tabulations show there is a general upward trend, this relationship may not be strictly linear, which the previous specification requires. This indicator variable then becomes a more robust way to measure the relationship between jury age and conviction rates. Consistent with this notion, we find there is a much stronger effect statistically when we use this indicator variable to measure age. In particular, Column 3 indicates that when the average age of the jury pool is greater than or equal to 50 , defendants are convicted 79 percent of the time. When the average age of the jury pool is less than 50, conviction rates are only 68 percent. Columns 5-8 repeat the same structure of the first four columns using the fraction of the first five offenses on which the defendant was found guilty as the dependant variable. The results are similar, although not all of the age coefficients are statistically significant.

Table 6 examines whether the relationship between juror age and conviction rates varies by defendant characteristics. To determine whether this relationship depends on defendant gender, Columns 1 and 2 regress whether a defendant is convicted of at least one crime on a measure of the age of the jury pool, whether the defendant is female, and an interaction of the two variables. The regressions also include controls for jury gender, race, and county, which are fully interacted with defendant gender; we also include controls for defendant race, crime type and total charges which are fully interacted with the age measure of the jury pool. ${ }^{26}$ The results in Column 2 indicate that for male defendants, when the

\footnotetext{
${ }^{26}$ Each control variable not shown in Table 6 is demeaned (prior to being interacted), which ensures the main coefficients in Table 6 are reported at the sample mean in each specification; thus there is no need to look at the coefficients on the interaction variables included in the vector of controls to interpret the main coefficients shown in the table.
} 
average age of the pool goes from below 50 to 50 or above, the conviction rates increase from $66 \%$ to $79 \%$. However, for female defendants the opposite pattern is observed as the conviction rate declines from $95 \%$ to $71 \%$. Because over 90 percent of the defendants are male, the overall pattern between juror age and conviction rates found in Table 5 mirrors that of male defendants.

Columns 3 and 4 of Table 6 perform a similar analysis, but now allow the relationship between juror age and conviction rates to depend on whether a defendant is black. These regressions restrict the sample to cases involving black and white defendants only. Again, we include controls for jury gender, race, and county which are fully interacted with defendant race; we also include controls for defendant gender, crime type and total charges which are fully interacted with the age measure of the jury pool. ${ }^{27}$ The results in Column 4 imply that the increase in conviction rates due to juror age is similar for cases involving black versus white defendants. Thus, the effects of juror age on conviction rates do not vary with the race of the defendant.

Table 7 runs some additional robustness checks on the main result found in Table 5. All specifications include the full set of controls, and use an indicator for whether the average age of the jury pool is greater than or equal to 50 as a measure of juror age (akin to Table 5, Column 4). The first two columns show that the positive relationship between juror age and conviction rates appears separately in both Lake and Sarasota County. Columns (3)-(5) consider the robustness of the results to alternative ways of categorizing trial outcomes that are not simple verdicts of "guilty" or "not guilty" by the jury. For instance, Column 3 redefines as guilty 133 cases in Lake County that are pled by the defendant at some point after a jury pool is chosen (but before the case actually goes to the jury). It is theoretically ambiguous whether such cases should be included in the analysis (categorized as guilty verdicts). On the one hand, it makes sense to include them if the willingness of the parties to enter into a plea bargain is affected by the composition of the jury. On the other hand, if these plea bargains are reached for reasons unrelated to the jury composition (as they would be if reached prior to jury selection), including them biases the coefficients towards zero as the outcome is, by construction, the same for all of these trials

\footnotetext{
${ }^{27}$ As above, each control variable not shown is demeaned prior to being interacted.
} 
regardless of the jury composition. ${ }^{28}$ Column 4 recodes those 25 Sarasota cases that did not have guilty or not guilty jury verdicts associated with them as not guilty while Column 5 repeats the same exercise, coding these cases as guilty. In all cases, the pattern of results related to juror age remains.

\section{Implications and Conclusion}

Sections IV and V have documented two main facts: (1) the prosecution tends to strike younger jurors while the defense tends to strike older jurors; and (2) increasing the age of the jury pool increases the likelihood a defendant will be found guilty of at least one crime. Given the ongoing debate about the use of peremptory challenges in the US legal system, we conclude the paper by discussing the implications of extending the protection against the discriminatory use of challenges on the basis of race and gender to age.

Most directly, the clear evidence that attorneys systematically exclude both the youngest and oldest members of the jury implies that including age as a protected category would provide these citizens with a more equal opportunity to be seated. ${ }^{29}$ When the youngest and oldest members of the pool are seated at greater rates, however, this would also increase the variance of the average age of seated juries. In particular, for the trials in our data set, if seven members of the jury pool were chosen at random to form each seated jury (plus the alternate) the standard deviation of the average age of seated juries would be 6.16 - which is 13 percent higher than the actual standard deviation reported in Table $1 .^{30}$ Given that age has a causal effect on trial outcomes, this in turn implies an increased variation in the outcomes of trials of comparable cases. Thus protecting jurors' rights appears to come with the cost of a more unequal application of criminal justice.

\footnotetext{
${ }^{28}$ It appears that many of the plea bargains included here are reached the day the case is scheduled to be heard in court but before voir dire begins. In particular, in about one-third of cases, we observe data characterizing the composition of the jury pool but not a seated jury, suggesting that voir dire did not actually occur in these cases.

${ }^{29}$ Note that a policy of eliminating age-based peremptory challenges will only have an effect if both the prosecution and defense attorneys abide by this when they strike potential jurors. The results presented in Section IV indicate this is likely to be the case, as both attorneys were shown to not use the already protected categories of race and gender in their selection decisions.

${ }^{30}$ The standard deviation of the population of jurors is approximately 16.3 . If seven jurors are chosen at random to form each seated jury, the standard deviation of the average age of seated juries should be approximately $16.3 / \sqrt{ } 7=$ 6.16 .
} 
But eliminating age-based peremptory challenges is not the only available policy instrument. In particular, the variance of the average age of juries is also directly related to the size of the jury. Thus, it is possible, for example, to maintain the current standard deviation of age across trials at 5.47 by increasing the size of randomly chosen juries to eight jurors plus an alternate. ${ }^{31}$ And, in fact, increasing jury size back to the standard size of twelve jurors plus an alternate would further reduce the standard deviation of average age to 4.52 . While many states have reduced the size of juries to save costs, this analysis points to a clear consequence of such policies - a substantial increase in the variance of trial outcomes for defendants with comparable cases.

Finally, it is worth stressing that any effects of age-based peremptory challenges on average conviction rates are likely mitigated by the symmetry of the peremptory challenges system. That is, while defense attorneys are able to systematically strike older members of the jury pool, prosecutors can do the exact opposite, thereby balancing the overall effect of peremptory challenges on trial outcomes. If the effect of age on trial outcomes is linear (and we do not detect any obvious non-linearities in our analysis), there will not be an impact on average conviction rates.

Such symmetry may not be present, however, whenever individuals with a particular attribute (e.g., race or religion) are a small minority of the local population. In such settings, without protection against discrimination, it may be possible for one side (prosecution or defense) to completely exclude members of the small minority from almost all juries. When there are large differences across these juror populations in the likelihood of convicting, such systematic exclusion might have a substantial impact on the average conviction rate. In particular, eliminating the restriction against the use of race as a basis for peremptory challenges could affect conviction rates in some jurisdictions.

\footnotetext{
${ }^{31}$ Note that $16.3 / \sqrt{ } 9=5.43$, which is quite close to 5.47 .
} 


\section{References}

Abrams, David, Marianne Bertrand, and Sendhil Mullainathan (forthcoming) "Do Judges Vary in Their Treatment of Race?" Journal of Legal Studies.

Abrams, David and Albert Yoon (2009),"The Luck of the Draw: Using Random Case Assignment to Investigate Attorney Ability," The University of Chicago Law Review, 74:4, 1145-1177.

Anwar, Shamena, Patrick Bayer, and Randi Hjalmarsson (forthcoming) "The Impact of Jury Race in Criminal Trials", The Quarterly Journal of Economics.

Baldwin, J. and Mike McConville (1980), "Understanding Jury Trial: A review of the Literature on the role of the Jury in Criminal trials in the United States and England", in (ed. N. Morris and M. Tonry), Crime and Justice 1979: A review of Criminal Justice Research, University of Chicago Press.

Baldus, D. C., Woodworth, G. G., Zuckerman, D., Weiner, N. A., \& Broffitt, B. (2001). "The use of peremptory challenges in capital murder trials: A legal and empirical analysis". University of Pennsylvania Journal of Constitutional Law, 3, 3-169.

Batson v. Kentucky (1986), 476 U.S. 79

Beck, Coburn (1998), "The Current State of the Peremptory Challenge," William and Mary Law Review, 39.

Bonazzoli, M. Juliet (1998-1999). "Jury Selection and Bias: Debunking Invidious Stereotypes through Science”. Quinnipiac Law Review, 18: 247.

Broderick, Raymond, (1992) "Why the Peremptory Challenge Should Be Abolished," 65 Temple Law Review 369

Chase, Carol and Colleen P. Graffy (1997) "A Challenge for Cause to Peremptory Challenges in Criminal Proceedings," 19 Loyola of Los Angeles International and Comparative Law Review 507.

Devine, Dennis, Laura Clayton, Benjamin Dunford, Rasmy Seying, and Jennifer Pryce (2000). "Jury Decision Making: 45 Years of Empirical Research on Deliberating Groups". Psychology, Public Policy, and Law, 7:3, 622-727.

Eisenberg, Theodore, Stephen Garvey, and Martin Wells (2001). "Forecasting Life and Death: Juror Race, Religion, and Attitude Toward the Death Penalty". Journal of Legal Studies, 30, 277-311.

Entzel, Pamela, Burton Dunlop and Max Rothman (2000) "Elders and Jury Service: A Case of Age Discrimination" In Rothman, Max, Burton Dunlop and Pamela Entzel (Eds), Elders, Crime, and the Criminal Justice System: Myth, Perceptions, and Reality in the $21^{\text {st }}$ Century, New York, Springer.

Fahey, William (1997) "Peremptory Challenges: A Crucial Tool for Trial Lawyers," 12 Criminal Justice 24

Hannaford-Agor, Paula, Valerie Hans, Nicole Mott, G. Thomas Munsterman (2002) "Are Hung Juries a Problem", National Institute of Justice, The National Center for State Courts. 
Hoffman, Morris (1997) "Peremptory Challenges Should Be Abolished: A Trial Judge's Perspective," 64 University of Chicago Law Review 809.

Garvey, Stephen, Paula Hannaford-Agor, Valerie Hans, Nicole Mott, G. Thomas Munsterman, and Martin Wells (2004). "Juror First Votes in Criminal Trials". Journal of Empirical Legal Studies, 1:2, 371398.

J.E.B. v Alabama (1994), ex rel. T.B., 511 U.S. 127

Johnson, Richard and David Neumark (1997) Age Discrimination, Job Separation, and the Employment Status of Older Workers: Evidence from Self-Reports," Journal of Human Resources, 32(4).

Kling, Jeffrey, "Incarceration Length, Employment, and Earnings," American Economic Review, 96 (2006), 863-876.

Macinol, John, (2005) Age Discrimination: An Historical and Contemporary Analysis, Cambridge University Press: Cambridge, UK

Marder, Nancy (1995) "Beyond Gender: Peremptory Challenges and the Roles of the Jury" Texas Law Review, 73, 1041-1138.

Mills, Carol and Wayne Bohannon (1980). "Jury Characteristics: To What Extent Are They Related to Jury Verdicts?" Judicature, 64, 22.

Montz, Vivien and Craig Lee Montz (2000), "The Peremptory Challenge: Should It Still Exist? An Examination of Federal and Florida Law," 54 University of Miami Law Review 451 (2000).

Montoya, Jean (1996) "The Future of Post-Batson Peremptory Challenges: Voir Dire By Questionnaire and the 'Blind Peremptory'”, 29 University of Michigan Journal of Legal Reform 981 (1996).

Moran, Gary and John Craig Comfort (1982). "Scientific Jury Selection: Sex as a Moderator of Demographic and Personality Predictors of Impaneled Felony Juror Behavior". Journal of Personality and Social Psychology, 1052-1054.

Neumark, David and Wendy Stock, (1999), "Age Discrimination Laws and Labor Market Efficiency," The Journal of Political Economy, 107(5).

Overland, Sean G. (2009). The Juror Factor: Race and Gender in America's Civil Courts, LFB Scholarly Publishing

Page, Anthony (2005), "Batson's Blind-Spot: Unconscious Stereotyping and the Peremptory Challenges," 85 Boston University Law Review 155.

Reid, Glen (2004), “Limitations on Peremptory Challenges: How Far Will They Extend?" 51 Fed. Law. 18.

State v. Hodge (1999), 248 Conn. 207, 726 A. 2d 531

Weber v. Strippit, Inc. (1999), 186 F.3d 907, 911 (8th Cir.) 
Table 1: Summary Statistics

\begin{tabular}{|c|c|c|c|c|c|c|}
\hline & \multicolumn{2}{|c|}{$\begin{array}{l}\text { All Lake and } \\
\text { Sarasota Cases }\end{array}$} & \multicolumn{2}{|c|}{ All Lake Cases } & \multicolumn{2}{|c|}{ All Sarasota Cases } \\
\hline & Mean & $\mathrm{Sd}$ & Mean & $\mathrm{Sd}$ & Mean & $\mathrm{Sd}$ \\
\hline \multicolumn{7}{|l|}{ Defendant Characteristics } \\
\hline Black Defendant & 0.439 & 0.497 & 0.501 & 0.501 & 0.382 & 0.486 \\
\hline Hispanic Defendant & 0.043 & 0.202 & 0.024 & 0.154 & 0.06 & 0.238 \\
\hline White Defendant & 0.513 & 0.500 & 0.472 & 0.500 & 0.551 & 0.498 \\
\hline Male Defendant & 0.919 & 0.273 & 0.931 & 0.254 & 0.908 & 0.29 \\
\hline \multicolumn{7}{|l|}{ Case Characteristics } \\
\hline Total Charges & 2.994 & 3.567 & 3.465 & 4.565 & 2.551 & 2.18 \\
\hline Any Drug Charge & 0.253 & 0.435 & 0.219 & 0.414 & 0.284 & 0.452 \\
\hline Any Murder Charge & 0.053 & 0.224 & 0.080 & 0.272 & 0.027 & 0.164 \\
\hline Any Robbery Charge & 0.090 & 0.287 & 0.099 & 0.299 & 0.082 & 0.275 \\
\hline Any Other Violent Charge & 0.307 & 0.461 & 0.349 & 0.477 & 0.267 & 0.443 \\
\hline Any Property Charge & 0.233 & 0.423 & 0.259 & 0.438 & 0.209 & 0.407 \\
\hline Any Sex Charge & 0.131 & 0.338 & 0.128 & 0.335 & 0.135 & 0.342 \\
\hline Any Weapons Charge & 0.120 & 0.325 & 0.160 & 0.367 & 0.082 & 0.275 \\
\hline Any Other Charge & 0.327 & 0.470 & 0.320 & 0.467 & 0.334 & 0.472 \\
\hline \multicolumn{7}{|l|}{ Dependant Variables } \\
\hline Proportion Guilty Convictions & 0.670 & 0.439 & 0.584 & 0.458 & 0.756 & 0.401 \\
\hline Any Guilty Convictions & 0.728 & 0.445 & 0.653 & 0.477 & 0.803 & 0.399 \\
\hline \multicolumn{7}{|l|}{ Pool and Seated Jury Characteristics } \\
\hline Number in Jury Pool & 27.292 & 7.294 & 26.956 & 7.410 & 27.613 & 7.175 \\
\hline Number of Seated Jurors & 7.113 & 0.483 & 7.307 & 0.500 & 6.928 & 0.384 \\
\hline Number of Jurors Struck for Cause & & & 2.229 & 2.357 & & \\
\hline $\begin{array}{l}\text { Number of Jurors Struck by Defense } \\
\text { Number of Jurors Struck by }\end{array}$ & & & 4.469 & 2.177 & & \\
\hline Prosecution & & & 3.383 & 1.874 & & \\
\hline average age of seated jury & 50.102 & 5.468 & 49.380 & 5.280 & 50.794 & 5.561 \\
\hline average age of pool & 49.623 & 3.137 & 49.361 & 3.164 & 49.873 & 3.094 \\
\hline average age of seated jury $>=50$ & 0.526 & 0.500 & 0.477 & 0.500 & 0.574 & 0.495 \\
\hline average age of pool $>=50$ & 0.461 & 0.499 & 0.424 & 0.495 & 0.496 & 0.501 \\
\hline Observations & 785 & & 384 & & 401 & \\
\hline
\end{tabular}

Note: The columns report summary statistics for the sample of cases for which a jury was selected and the variable under consideration is defined. In the first column, defendant race is defined for 774 cases, defendant gender for 776 cases, specific crime categories for 776 cases, total charges for 773 cases, the dependant variables for 750 cases, and the pool and seated jury variables for the full sample of 785 cases. Summary statistics for the proportion and average variables (i.e., proportion guilty convictions, average age of seated jury, and average age of pool) were formed by measuring the relevant proportion or average for each jury/jury pool and then averaging across cases. 
Table 2: Juror Selection in Lake County

\begin{tabular}{lccc}
\hline & juror age & $\begin{array}{c}\text { indicator for whether } \\
\text { juror is male }\end{array}$ & $\begin{array}{c}\text { indicator for whether } \\
\text { juror is black }\end{array}$ \\
\hline struck for cause & 0.683 & $-0.0394^{* *}$ & 0.0119 \\
& $(0.534)$ & $(0.0195)$ & $(0.0103)$ \\
struck by defense & $2.186^{* * *}$ & -0.0160 & $-0.0362^{* * *}$ \\
& $(0.417)$ & $(0.0153)$ & $(0.00614)$ \\
struck by prosecution & $-2.321^{* * *}$ & -0.00513 & $-0.0160^{* *}$ \\
& $(0.488)$ & $(0.0168)$ & $(0.00762)$ \\
remained in pool & -0.340 & -0.0163 & -0.00757 \\
& $(0.350)$ & $(0.0127)$ & $(0.00612)$ \\
constant & & & $0.0630^{* * *}$ \\
& $(0.259)$ & $0.503 * * *$ & $(0.00468)$ \\
\hline Observations & 10185 & $(0.00944)$ & 9753 \\
\hline R-squared & 0.008 & 10185 & 0.004 \\
\hline
\end{tabular}

Note: The omitted category is an indicator for whether the juror was seated. All regressions use OLS and report heteroskedasticity-robust standard errors in parentheses. $*, * *$, and $* * *$ indicate statistical significance at the 10 percent, 5 percent, and 1 percent levels, respectively. Columns 1 and 2 include all jurors in the pool for the 384 Lake County trials. Column 3 restricts this to white and black jurors only. 
Table 3: The Relationship between the Age Composition of the Jury Pool and Defendant/Case Characteristics

(1) (2)

Indicator for whether

Average Age of Pool Average Age of Pool $>=50$

\begin{tabular}{|c|c|c|}
\hline \multicolumn{3}{|l|}{ Defendant Characteristics } \\
\hline \multirow[t]{2}{*}{ Black Defendant } & -0.295 & -0.0320 \\
\hline & $(0.260)$ & $(0.0405)$ \\
\hline \multirow[t]{2}{*}{ Hispanic Defendant } & 0.227 & -0.0474 \\
\hline & $(0.679)$ & $(0.0910)$ \\
\hline \multirow[t]{2}{*}{ Male Defendant } & $-0.796^{*}$ & $-0.122 *$ \\
\hline & $(0.450)$ & $(0.0676)$ \\
\hline \multicolumn{3}{|l|}{ Case Characteristics } \\
\hline \multirow[t]{2}{*}{ Any Drug Charge } & 0.222 & 0.0198 \\
\hline & $(0.328)$ & $(0.0534)$ \\
\hline \multirow[t]{2}{*}{ Any Murder Charge } & 0.159 & -0.0333 \\
\hline & $(0.414)$ & $(0.0834)$ \\
\hline \multirow[t]{2}{*}{ Any Other Charge } & 0.0812 & -0.0179 \\
\hline & $(0.261)$ & $(0.0425)$ \\
\hline \multirow{2}{*}{$\begin{array}{c}\text { Any Other Violent } \\
\text { Charge }\end{array}$} & 0.216 & 0.00881 \\
\hline & $(0.267)$ & $(0.0440)$ \\
\hline \multirow[t]{2}{*}{ Any Property Charge } & 0.0827 & -0.00943 \\
\hline & $(0.301)$ & $(0.0500)$ \\
\hline \multirow[t]{2}{*}{ Any Robbery Charge } & 0.343 & 0.0874 \\
\hline & $(0.411)$ & $(0.0662)$ \\
\hline \multirow[t]{2}{*}{ Any Sex Charge } & 0.572 & 0.0751 \\
\hline & $(0.402)$ & $(0.0639)$ \\
\hline \multirow[t]{2}{*}{ Any Weapons Charge } & 0.157 & -0.0470 \\
\hline & $(0.332)$ & $(0.0572)$ \\
\hline \multirow[t]{2}{*}{ Total Charges } & -0.0422 & -0.00464 \\
\hline & $(0.0388)$ & $(0.00622)$ \\
\hline \multirow[t]{2}{*}{ Constant } & $50.30 * * *$ & $0.593 * * *$ \\
\hline & $(0.473)$ & $(0.0744)$ \\
\hline Observations & 771 & 771 \\
\hline F-Statistic & 0.67 & 0.84 \\
\hline R-squared & 0.01 & 0.01 \\
\hline
\end{tabular}

Note: All regressions use OLS and report heteroskedasticity-robust standard errors in parentheses. ${ }^{*},{ }^{* *}$, and $* * *$ indicate statistical significance at the 10 percent, 5 percent, and 1 percent levels, respectively. The crime categories are not mutually exclusive, so there is no omitted crime category. F-statistics jointly testing whether all coefficients equal zero are reported in the second to last row of the table. Fourteen observations from the full sample shown in Table 1 were dropped due to one or more missing values for the various defendant and case characteristics. 
Table 4: Cross Tabulations of Conviction Rates and Age Composition of Jury Pool

\begin{tabular}{|c|c|c|c|c|}
\hline & & $\begin{array}{l}\text { No Guilty } \\
\text { Verdicts }\end{array}$ & $\begin{array}{l}\text { At Least One } \\
\text { Guilty Verdict }\end{array}$ & Conviction Rate \\
\hline$\stackrel{\geqq}{\Xi}$ & $40-45$ & 18 & 30 & $63 \%$ \\
\hline 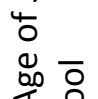 & $45-50$ & 112 & 243 & $68 \%$ \\
\hline 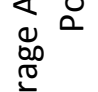 & $50-55$ & 64 & 252 & $80 \%$ \\
\hline$\stackrel{0}{2}$ & $55-60$ & 9 & 20 & $69 \%$ \\
\hline
\end{tabular}

Note: 35 observations from the full sample used in Table 1 were dropped because none of the charged offenses for those trials resulted in a verdict of guilty or not guilty by the jury. An additional two observations are not included in this table because the average age of the pool was less than 40 . 
Table 5: Reduced Form Regressions of Relationship Between Conviction Rates and Age of Jury Pool

(1)

(2)

(3)

(4)

(5)

(6)

(7)

(8)

Any Guilty Conviction

Proportion Guilty Convictions

\begin{tabular}{|c|c|c|c|c|c|c|c|c|}
\hline Average Age of & $0.0104 *$ & $0.00891^{*}$ & & & 0.00761 & 0.00525 & & \\
\hline & $(0.00534)$ & $(0.00538)$ & & & $(0.00527)$ & $(0.00537)$ & & \\
\hline $\begin{array}{l}\text { Average Age of } \\
\text { Pool }>=50\end{array}$ & & & $\begin{array}{l}0.112 * * * \\
(0.0320)\end{array}$ & $\begin{array}{l}0.116^{* * *} \\
(0.0333)\end{array}$ & & & $\begin{array}{c}0.0914 * * * \\
(0.0318)\end{array}$ & $\begin{array}{c}0.0899 * * * \\
(0.0331)\end{array}$ \\
\hline Constant & $\begin{array}{c}0.210 \\
(0.267)\end{array}$ & $\begin{array}{c}1.231 * * \\
(0.602)\end{array}$ & $\begin{array}{c}0.677 * * * \\
(0.0233)\end{array}$ & $\begin{array}{c}1.673 * * * \\
(0.540)\end{array}$ & $\begin{array}{c}0.292 \\
(0.263)\end{array}$ & $\begin{array}{l}1.301 * * \\
(0.596)\end{array}$ & $\begin{array}{l}0.628 * * * \\
(0.0227)\end{array}$ & $\begin{array}{c}1.577 * * * \\
(0.536)\end{array}$ \\
\hline Controls & none & full & none & full & none & full & none & full \\
\hline Observations & 750 & 743 & 750 & 743 & 750 & 743 & 750 & 743 \\
\hline R-Squared & 0.005 & 0.119 & 0.016 & 0.131 & 0.003 & 0.117 & 0.011 & 0.125 \\
\hline
\end{tabular}


Table 6: Robustness of Main Result to Defendant Gender and Race

Dependent Variable $=$ Any Guilty Conviction

(1)

\author{
Average Age of Pool
}

Female Defendant

Average Age of Pool* Female Defendant

Average Age of Pool $>=50$

Average Age of Pool $>=50$ * Female Defendant

Black Defendant

Average Age of Pool * Black Defendant

Average Age of Pool $>=50 *$ Black Defendant

$(0.0185)$

$\begin{array}{ccc}0.0109 * & & 0.0109 \\ (0.00583) & & (0.00819) \\ 2.529 * * * & 0.282 * * * & \\ (0.928) & (0.0755) & \\ 0.0488 * * * & \end{array}$

$-0.0488 * * *$

$\begin{array}{lc}0.131 * * * & 0.145^{* * *} \\ (0.0343) & (0.0481)\end{array}$

$0.365 * * *$

(0.126)

$\begin{array}{cc}0.0530 & 0.0825 \\ (0.624) & (0.0504) \\ 0.000303 & \\ (0.0126) & \end{array}$

(0.0126)

$-0.0287$

$(0.0741)$

$0.626^{* * *}$

\begin{tabular}{ccccc} 
Constant & 0.187 & $0.664^{* * *}$ & 0.156 & $0.626^{* * *}$ \\
& $(0.290)$ & $(0.0240)$ & $(0.406)$ & $(0.0336)$ \\
\hline Observations & 746 & 746 & 710 & 710 \\
R-squared & 0.135 & 0.154 & 0.130 & 0.152
\end{tabular}

Note: All regressions use OLS and report heteroskedasticity-robust standard errors in parentheses. *,**, and *** indicate statistical significance at the 10 percent, 5 percent, and 1 percent levels, respectively. Columns 1 and 2 include demeaned controls for jury gender, race, and county, which are fully interacted with defendant gender, as well as demeaned controls for defendant race, crime type and total charges which are fully interacted with the age measure of the jury pool. Columns 3 and 4 include demeaned controls for jury gender, race and county which are fully interacted with defendant race, as well as demeaned controls for defendant gender, crime type, and total charges which are fully interacted with the age measure of the jury pool. Columns 3 and 4 restrict the sample to cases with black and white defendants only. 
Table 7: Robustness/Sensitivity Checks

Dependent Variable $=$ Any Guilty Conviction

(1)

(2)

(3)

(4)

(5)

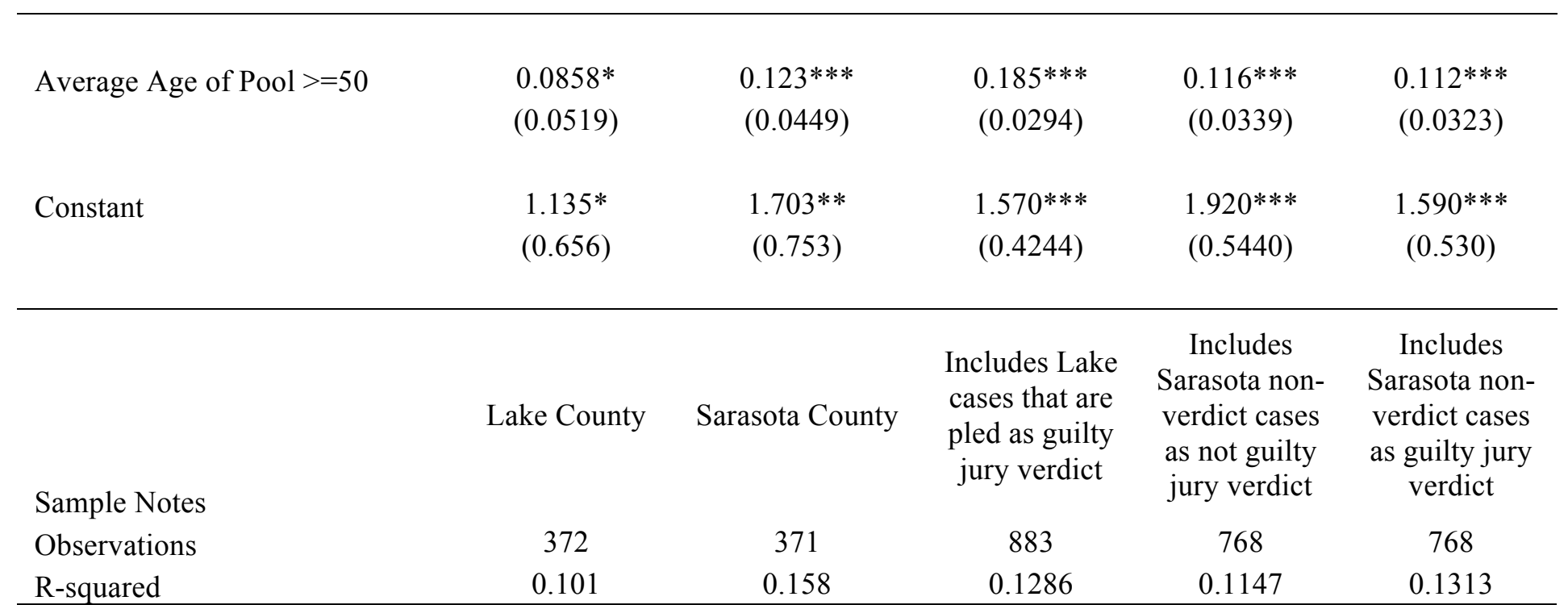

Note: All regressions use OLS and report heteroskedasticity-robust standard errors in parentheses. ${ }^{*},{ }^{* *}$, and $* * *$ indicate statistical significance at the 10 percent, 5 percent; and 1 percent levels, respectively. All regressions include the full set of controls described in Table 5. 